\title{
A Midwest USA Perspective on Von Cossel et al.'s Prospects of Bioenergy Cropping Systems for a More Social-Ecologically Sound Bioeconomy
}

\author{
Kenneth J. Moore ${ }^{1, *(D)}$, Catherine Louise Kling ${ }^{2}$ and D. Raj Raman ${ }^{3}(\mathbb{D}$ \\ 1 Department of Agronomy, Iowa State University, Ames, IA 50011, USA \\ 2 Dyson School of Applied Economics and Management, Faculty Director Cornell Atkinson Center for \\ Sustainability, Cornell University, Ithaca, NY 14853, USA; ckling@cornell.edu \\ 3 Agricultural and Biosystems Engineering, Iowa State University, Ames, IA 50011, USA; rajraman@iastate.edu \\ * Correspondence: kjmoore@iastate.edu; Tel.: +1-515-294-5482
}

Received: 9 October 2020; Accepted: 26 October 2020; Published: 28 October 2020

\begin{abstract}
Bioenergy cropping systems afford the prospect to provide a more socially and ecologically sustainable bioeconomy. By creating opportunities to diversify agroecosystems, bioenergy crops can be used to fulfill multiple functions in addition to providing more environmentally benign fuels. Bioenergy crops can be assembled into cropping systems that provide both food and energy and which also provide cleaner water, improved soil quality, increased carbon sequestration, and increased biological diversity. In so doing, they improve the resilience of agroecosystems and reduce risks associated with climate change. Beyond the farmgate, bioenergy crops can improve the economic prospects of rural communities by creating new jobs and providing opportunities for local investment.
\end{abstract}

Keywords: bioenergy crop; bioeconomy; cropping system; marginal land

\section{The Midwest USA Context}

Assembling bioenergy cropping systems to achieve multiple goals depends greatly on the ecological and social context where they are to be deployed [1]. The Midwest USA is a nexus of agricultural productivity, biofuel production, and water quality issues. The region produces nearly $40 \%$ of the world's maize. More than a third of its maize production is used to produce ethanol for transportation fuels, a fourfold increase over the past decade and a half. However, using current production practices, removing maize residues as a feedstock for cellulosic ethanol production will have negative effects on soil and water quality [2-4]. These include increased soil erosion and nitrogen, phosphorus, and pesticide pollution of surface and ground water, degraded soil health, and an increase in the size of the hypoxic zone in the Gulf of Mexico [5]. Furthermore, climate projections suggest that this region will increasingly face droughts, floods, extreme rains, and other conditions detrimental to agriculture [6]. Integration of advanced biofuel production systems with strategic landscape-based systems for producing crop residue and perennial grass biomass feedstocks will improve both agronomic and environmental resilience.

The predominant crops grown in the Midwest USA are maize (Zea mays L.) and soybean (Glycine max (L.) Merr.). Both crops are well adapted to the region and have received substantial commercial and public investment in their improvement and supporting infrastructure. Both crops can be used in food, livestock feed, and for industrial purposes including biofuels. There are concerns with using land capable of producing food for bioenergy as expressed in the review by Von Cossel et al. [1]. However, in addition to producing high grain yields, maize produces an approximately equal amount of crop residue, a portion of which can be harvested for second generation biofuel 
production [4]. Maize therefore can serve dual purposes enabling food and advanced biofuel to be produced simultaneously on the same land. Residues remaining after maize harvest represent the largest available supply of cellulosic biomass in the USA [7].

\section{Potential for Providing Food, Bioenergy, and Conservation Benefits}

The amount of maize residue that can be sustainably harvested depends on soil and other characteristics of the site where it is grown $[3,4]$. Crop residues are generally returned to the field to provide soil cover during the interval between harvest and the establishment of the next crop. Cropland is especially vulnerable to wind and water erosion during this period and removing too much stover can lead to severe soil loss. There are cropping practices that can mitigate these negative impacts by providing alternative plant cover during what is normally a fallow period. Double cropping with a winter annual grain is feasible in the southern part of the region and produces crop residues that could also be used to produce biofuel [8]. This is not an option in the northern part of the region but growing a winter annual such as rye (Secale cereale $\mathrm{L}$.) or triticale $(\times$ Triticosecale spp.) provides winter cover while producing biomass for biofuel production $[9,10]$. An emerging approach is to intercrop maize with a perennial groundcover [11]. In these systems, perennial species such as kentucky bluegrass (Poa pratensis L.), creeping red fescue (Festuca rubra L.), kura clover (Trifolium ambiguum M. Bieb.), and white clover (Trifolium repens L.) are grown primarily for environmental reasons, but in some cases are harvested as a forage crop [11-13]. Growing maize with perennial groundcover more than doubles the quantity of biomass that can be sustainably harvested in this system, significantly increasing the density of biomass available within a fuel shed and thereby reducing haul distance and transportation costs. In the USA, low commercial energy prices mean that bioenergy systems have to be very efficient to ensure cost-competitiveness. Furthermore, lower yielding biomass feedstocks not only struggle to compete on price, which reduces the likelihood of long-term widespread adoption, they create indirect land use impacts that negatively impact some of their environmental benefits $[14,15]$.

The environmental and economic impacts of maize-soybean production are large because of its large footprint on the landscape-over 70 million hectares in 2019 [16]. It is the aggregate impact on these millions of hectares that results in large-scale negative impact that impairs water quality in the Mississippi river basin and culminates in Gulf Hypoxia [5]. Any meaningful solution to these problems must address land use at this scale. Integrating bioenergy crops into the maize-soybean cropping system provides an opportunity to better manage environmental impacts by regenerating ecosystem services that were lost with the native flora [16] (Figure 1). 


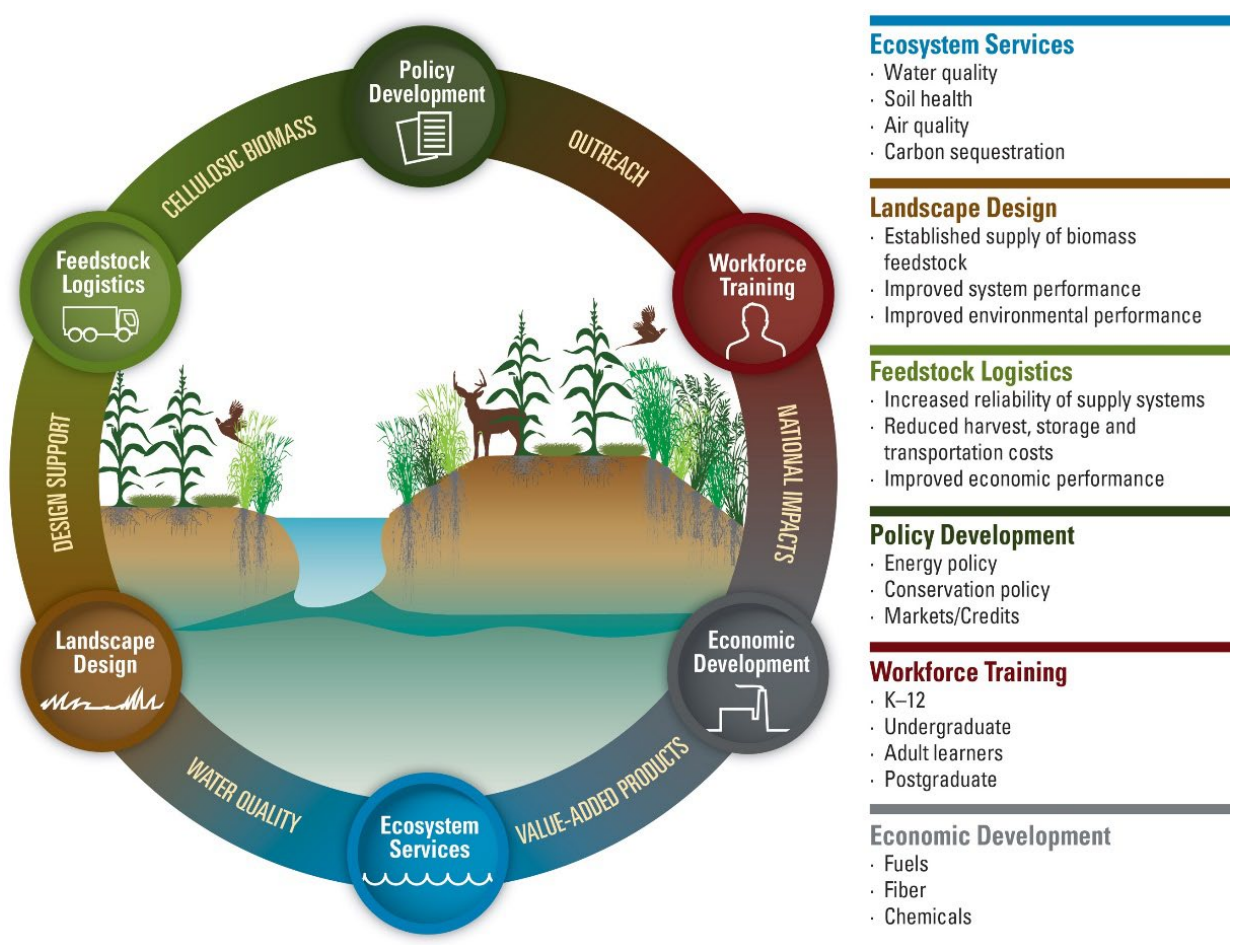

Figure 1. Conceptual representation of the Midwest sustainable biofuels vision. The prospect of integrating bioenergy crops into agricultural landscapes creates an opportunity to diversify cropping systems resulting in enhanced ecosystem services and economic development. (Drawing by Christine Hobbs, Hobbs Designs, LLC.)

\section{Strategic Inclusion of Bioenergy Crops}

In the Midwest USA, bioenergy crops can be strategically placed in the landscape to achieve conservation goals. CenUSA Bioenergy was a large multi-institution research, education and outreach project focused on growing perennial bioenergy crops on marginal land [14]. The definition of marginal land used in CenUSA was broader in scope than that put forth by Von Cossel et al. [1] as it also included less productive land that is economically marginal, in that it is not consistently profitable to grow commodity crops due to poor agronomic conditions. When prices are high, commodity crops can be grown profitably. However, when prices are low, this land is farmed less intensively and a portion of it is used for other purposes or enrolled in conservation programs. It has been estimated that about 20 percent of the land within the Midwest USA can be considered marginal by this definition which incorporates both economic and environmental components of sustainability.

Growing perennial bioenergy crops such as switchgrass (Panicum virgatum L.), reed canarygrass (Phalaris arundinacea L.) and other herbaceous perennial crops on marginal land can significantly reduce delivery of sediment and other agricultural pollutants from farm fields [17]. By intercepting surface flow, they trap displaced soil moving with the water and prevent its delivery to streams, rivers and lakes. Perennial bioenergy crops are particularly well suited to lowlands adjacent to waterways where they provide a buffer zone. Several species are well adapted to these zones and tolerate periods of flooding and saturated soil [18]. A significant proportion of land in riparian zones is considered highly erodible and is targeted by conservation programs intended to limit soil erosion and protect water quality. From an environmental perspective, it would be ideal for none of this land to be tilled and exposed to further degradation. Perennial bioenergy crops offer a possible option for obtaining an economic return from this land while supporting conservation goals.

Bonner et al. [19] developed a landscape design approach using a multi-objective optimization procedure. The method used the Landscape Environmental Assessment Framework (LEAF) to assess agronomic performance and soil health and assessed potential water quality using the Water Quality 
Index for Agricultural Lands (WQIag). They demonstrated that better environmental and economic outcomes were attainable by developing management zones based on the differential performance of maize and switchgrass. Using this subfield bioenergy integration strategy, soil erosion was reduced by 63 percent, carbon sequestration increased 69 percent, and yield of biomass that could be sustainably harvested increased by 35 percent.

Targeting where to grow bioenergy crops within fields to optimize economic and environmental impacts can be achieved using data collected from yield monitors that are commonly used in grain harvesters [20]. In the AgSolver approach, fields are evaluated for profitability on a spatial basis using long-term yield data, production costs, and commodity price information. Farm fields are subdivided into subfields based on their profitability over several years. These areas are categorized as land that is nearly always profitable for grain production, land that is rarely or never profitable, and land for which profitability is highly variable. Based on this information, producers can make land allocation decisions based on risks associated with each subfield category. Land that is identified as being unprofitable for grain production often coincides with land that poses a greater risk for soil erosion. Growing perennial bioenergy crops with much lower input costs on this land would provide potential economic returns while providing conservation benefits. Land with high profit variability could be allocated to long-term crop rotations that could include a perennial energy crop phase [21]. Alternatively, it could be used to grow annual crops for biorenewable products such as sorghum (Sorghum bicolor (L.) Moench) and kenaf (Hibiscus cannabinus L.) [22,23].

\section{Realizing the Potential of Bioenergy Crops}

The low prices of fossil energy mean that biomass feedstock materials are often worth significantly more for other uses than for energy [24]. Despite decades of research and development, fuels produced from cellulosic bioenergy crops have not achieved widespread commercial deployment, for a variety of reasons ranging from the challenges of harvesting, storing, transporting, and processing a relatively low-energy-density feedstock, to the extremely low prices of fossil fuels. Along with a pandemic-driven move toward tele-work, the growing electrification of surface road vehicles puts further downward pressure on oil prices which directly impact the prices for biofuels and associated feedstock. Aviation's need for high-energy-density fuels is a potential niche for biofuels [25]. The gap between the cost of production and what processors would be willing to pay has narrowed but remains an obstacle to large-scale adoption without policies that alter the relative profitability of bioenergy cropping systems and traditional grain production. Specifically, for bioenergy crops to be adopted by growers in the Midwest USA, their profitability must be able to compete favorably with maize and soybean.

There are three principal ways in which the profitability of bioenergy crops can be improved: (1) improve the efficiency of production, harvesting, transportation and storage of cellulosic feedstock to reduce costs associated with these activities; (2) develop alternative higher value uses for biomass feedstocks that can be profitable with high feedstock costs; (3) develop and implement policies at the federal (and/or state) levels that increase the profitability of cropping systems that provide environmental services so that the societal benefits of using perennial bioenergy crops to produce biofuels and bioproducts and attenuate negative environmental impacts are incorporated in farm-level decision making.

\section{Reducing Production, Harvesting, and Transportation Costs}

Increasing biomass yield potential is the most direct way to reduce production costs. Development of high-yielding cultivars of bioenergy crops is a long process, but significant progress has been made in recent years [26,27]. Vogel et al. [28] developed the first biomass cultivar adapted to the Midwest USA. "Liberty" switchgrass was created by crossing an upland with a lowland cultivar and selecting among the progeny for winter survival and yield. It combines the winter hardiness of upland varieties with the high yield potential of lowland varieties and is well adapted to the Midwest growing 
environment. Casler and Vogel [27] cite a 25\% reduction in production costs for switchgrass biomass over a ten-year period associated with growing adapted cultivars. Sorghum is another crop that has been bred for biomass traits $[29,30]$. Sorghum has better drought tolerance than maize and better nitrogen use efficiency. Consequently, it is better adapted to marginal sites that are inherently less productive [31]. There are other bioenergy crops for which cultivar development is in progress including pennycress (Thlaspi arvense L.), camelina (Camelina sativa (L.) Crantz), and miscanthus (Miscanthus spp.). Improved crop management, including better nutrient and pest management, can also increase biomass yield [32,33].

Harvesting crop residues and dedicated bioenergy crops is both a labor and energy intensive process that involves cutting, often field curing, and packaging the biomass into modules that can be safely transported and stored. Harvesting efficiency can be improved by improving crop drying rate [34] and strategic placement of bales within a field to facilitate handling [35]. Transportation costs can be reduced by densifying harvested biomass so that truck loads are limited by weight rather than volume [36].

\section{Broadening the Market for Biomass}

Technological progression typically follows a trajectory from low-volume production at relatively high selling prices, to higher volumes at lower prices. First generation biofuels from both starch and sugar sources were based upon crops produced at large volume and low price prior to their use as biofuel feedstocks $[37,38]$. The low cost of energy makes launching a new biomass energy crop particularly challenging. Compounding this challenge is the small size of the lignocellulosic biofuels processing industry [39]. One way of overcoming the price and volume challenge is to identify non-energy uses for novel biomass feedstock, for example, as bedding or roughage, which may provide demand and pricing that can support the roll-out of a new crop [40].

\section{Public Policies to Incentivize Biomass Production}

Grain farmers across the Midwest, like all businesses, are subject to economic forces that dictate their ability to remain profitable. Farmers regularly face volatile growing conditions which can result in highly variable returns from year to year. Nonetheless, the average net returns to maize farmers across the USA (excluding government payments) has averaged over \$310/acre since 2007 [41,42]. Including government payments would add considerably to the latest years' figures. Large-scale adoption of perennial feedstocks and/or cover crops will not occur until these systems compete favorably on a regular basis with this level of profitability.

Public policy can tip the scales towards bioenergy crop adoption in one of two ways: (1) policies that raise the net returns to these alternative systems (such as subsidies for farmers who adopt these systems and/or cellulosic biofuel mandates implemented via approaches like the renewable fuels standard), or (2) policies that increase the market price of competing products (such as carbon taxes on fossil fuels). The former approach has largely characterized the USA policy for expanding markets for bioenergy crops and incenting environmental improvements in grain production. The Renewable Fuel Standard (RFS) mandates targets for three categories of biofuels: (1) conventional biofuels, (2) advanced biofuels, and (3) cellulosic biofuels [43]. By assuring investors of a reliable market and raising returns to grain farmers, the RFS was remarkably effective in establishing a viable industry for producing conventional biofuels. Growth in the conventional biofuel industry mirrored production targets set by the RFS and underscores the potential for public policy to catalyze investment in alternative fuels.

Unfortunately, the RFS has not been as successful in spurring development of advanced and cellulosic biofuels. There are several reasons for this failure including technological barriers, high capital costs of building out biorefineries, cost and availability of feedstocks, and the historically low fossil energy prices that coincided with the first large-scale deployments of cellulosic ethanol plants [44]. Nevertheless, the incentive structure of the approach is sound as it raises returns to cellulosic production. By setting new and aggressive targets for advanced biofuels when the law expires in 2022, the USA can substantially diversify the portfolio of crops that can be economically grown. 
Another approach to increasing net returns from bioenergy crops is to value their environmental benefits and compensate farmers for growing them. The Conservation Reserve Program expends USA taxpayer monies to compensate farmers for taking their land out of production and has been estimated to have generated USD 428 million per year in wildlife viewing and hunting and nearly USD 40 million in freshwater recreation benefits [45]. Other noteworthy programs in this vein included the Environmental Quality Incentive Program, the Wetlands Reserve Program, and the Conservation Stewardship Program. While this is an appealing approach to some, even the current taxpayer bill associated with these programs is formidable. In 2019 alone, taxpayers provided more than USD 1.7 billion in payments [46] to owners of 22 million acres. The costs to taxpayers to incentivize large scale perennial feedstocks and cover crop adoption would likely exceed this figure.

Yet another approach that the USA has already adopted is conservation compliance which ties crop insurance and other subsidies directly to requirements that conservation practices be implemented. While there is evidence that this policy has returned environmental gains to taxpayers [47], the policy would need to be significantly expanded to require and enforce adoption of bioenergy cropping systems (including perennials).

Other hybrid approaches are possible: taxpayer dollars could be moderately expanded to provide partial cost offsets for farmers planting perennial feedstocks while allowing farmers to harvest and sell their biomass at market prices. Additionally, fertilizer taxes could be levied to encourage the adoption of bioenergy crops while simultaneously providing revenue that could be used to support wetlands and floodplain restoration that filter nutrients from upstream farms in a watershed.

As long as biofuels are in competition with fuels derived from inexpensive fossil energy sources, establishment of a competitive industry will struggle without government intervention. It bears emphasizing that a federal policy that raises the price of products produced with carbon intensive approaches will be required for the entire economy to shift the balance to carbon neutral biofuels, but other policies can and should play an important role.

\section{Summary and Conclusions}

Diversifying the maize-soybean production system with biomass crops has the potential of addressing the trilemma of food, environment, and energy [1,48]. It would lead to improved environmental outcomes including cleaner water and healthier soils. It would provide alternative feedstock for producing fuels but also for replacing other petroleum-derived products with biorenewable ones. Intentionally targeting bioenergy crop production to marginal land would provide significant conservation benefits with minimal impacts on food and feed production.

Achieving the prospect of a more socio-ecologically sound bioeconomy through the development and deployment of bioenergy cropping systems will require significant public investment. To be adopted in the Midwest USA, bioenergy cropping systems must be able to compete favorably with maize and soybean. Public policies that incentivize bioenergy crop production will be necessary to achieve profitability for the foreseeable future.

Funding: This research received no external funding.

Acknowledgments: The authors of this editorial were co-directors of CenUSA Bioenergy, a USDA National Institute of Food and Agriculture Coordinate Agricultural Project that explored creating a regional system for producing advanced transportation fuels and other bio-based products from perennial grasses grown on land that is either unsuitable or marginal for row crop production in the Midwest USA. Visit https://cenusa.iastate.edu/ to learn more about the project. The opinions expressed are those of the authors and may not reflect those of the USDA or the institutions where they are employed.

Conflicts of Interest: The authors declare no conflict of interest. 


\section{References}

1. Von Cossel, M.; Wagner, M.; Lask, J.; Magenau, E.; Bauerle, A.; Von Cossel, V.; Warrach-Sagi, K.; Elbersen, B.; Staritsky, I.; Van Eupen, M.; et al. Prospects of Bioenergy Cropping Systems for A More Social-Ecologically Sound Bioeconomy. Agronomy 2019, 9, 605. [CrossRef]

2. Wilhelm, W.W.; Johnson, J.M.F.; Hatfield, J.L.; Voorhees, W.B.; Linden, D.R. Crop and soil productivity response to corn residue removal: A literature review. Agron. J. 2004, 96, 1-17. [CrossRef]

3. Wilhelm, W.W.; Johnson, J.M.F.; Karlen, D.L.; Lightle, D.T. Corn stover to sustain soil organic carbon further constrains biomass supply. Agron. J. 2007, 99, 1665-1667. [CrossRef]

4. Moore, K.J.; Karlen, D.L.; Lamkey, K.R. Future prospects for corn as a biofuel crop. In Compendium of Bioenergy Crops; Goldman, S.L., Ed.; Science Publishers: Rawalpindi, Pakistan; Taylor \& Francis Group, LLC: Abingdon, UK, 2014; pp. 331-352.

5. Porter, P.A.; Mitchell, R.B.; Moore, K.J. Reducing hypoxia in the Gulf of Mexico: An alternative approach. J. Soil Water Conserv. 2015, 70, 63A-68A. [CrossRef]

6. Cook, B.I.; Ault, T.R.; Smerdon, J.E. Unprecedented 21st Century drought risk in the American Southwest and Central Plains. Sci. Adv. 2015, 1, e1400082. [CrossRef]

7. US-DOE. 2016 Billion-Ton Report: Advancing Domestic Resources for a Thriving Bioeconomy, Volume 1: Economic Availability of Feedstocks; ORNL/TM-2016/160; Oak Ridge National Laboratory: Oak Ridge, TN, USA, 2016.

8. Moore, K.J.; Karlen, D.L. Double cropping opportunities for biomass crops in the north central USA. Biofuels 2013, 4, 605-615. [CrossRef]

9. Blanco-Canqui, H.; Shaver, T.M.; Lindquist, J.L.; Shapiro, C.A.; Elmore, R.A.; Francis, C.A.; Hergert, G.W. Cover crops and ecosystem services: Insights from studies in termperate soils. Agron. J. 2015, 107, 2449-2474. [CrossRef]

10. Bonner, I.J.; Muth, D.J.; Koch, J.B.; Karlen, D.L. Modeled impacts of cover crops and vegetative barriers on corn stover availability and soil quality. BioEnergy Res. 2014, 7, 576-589. [CrossRef]

11. Moore, K.J.; Anex, R.P.; Elobeid, A.E.; Fei, S.; Flora, C.B.; Goggi, A.S.; Jacobs, K.L.; Jha, P.; Kaleita, A.L.; Karlen, D.L.; et al. Regenerating Agricultural Landscapes with Perennial Groundcover for Intensive Crop Production. Agronomy 2019, 9, 458. [CrossRef]

12. Sanders, Z.P.; Andrews, J.S.; Saha, U.K.; Vencill, W.; Lee, R.D.; Hill, N.S. Optimizing agronomic practices for clover persistence and corn yield in a white clover-corn living mulch system. Agron. J. 2017, 109, 2025-2032. [CrossRef]

13. Andrews, J.S.; Sanders, Z.P.; Cabrera, M.L.; Saha, U.K.; Hill, N.S. Nitrogen dynamics in living mulch and annual cover crop corn production systems. Agron. J. 2018, 110, 1309-1317. [CrossRef]

14. Moore, K.J.; Birrell, S.; Brown, R.C.; Casler, M.D.; Euken, J.E.; Hanna, H.M.; Hayes, D.J.; Hill, J.D.; Jacobs, K.L.; Kling, C.L.; et al. Midwest vision for sustainable fuel production. Biofuels 2015, 5, 687-702. [CrossRef]

15. Lask, J.; Guajardo, A.M.; Weik, J.; von Cossel, M.; Lewandowski, I.; Wagner, M. Comparative environmental and economic life cycle assessment of biogas production from perennial wild plant mixtures and maize (Zea mays L.) in southwest Germany. GCB Bioenergy 2020, 12. [CrossRef]

16. USDA-NASS. Crops and Plants. 2020. Available online: https://www.nass.usda.gov/ (accessed on 5 October 2020).

17. Casler, M.D.; Cherney, J.H.; Brummer, E.C. Biomass yield of naturalized populations and cultivars of reed canary grass. Bioenergy Res. 2009, 2, 165-173. [CrossRef]

18. Ruf, T.; Audu, V.; Holzhauser, K.; Emmerling, C. Bioenergy from periodically waterlogged cropland in europe: A first assessment of the potential of five perennial energy crops to provide biomass and their interactions with soil. Agronomy 2019, 9, 374. [CrossRef]

19. Bonner, I.; McNunn, G.; Muth, D., Jr.; Tyner, W.; Leirer, J.; Dakins, M. Development of integrated bioenergy production systems using precision conservation and multicriteria decision analysis techniques. J. Soil Water Conserv. 2016, 71, 182-193. [CrossRef]

20. Muth, D. Profitability versus environmental performance: Are they competing? J. Soil Water Conserv. 2014, 69, 203A-206A. [CrossRef]

21. Aller, D.; Laird, D.; Zhang, W.; Sawadgo, W.; Moore, K. Long term biochar effects on corn yield, soil quality and profitability in the US Midwest. Field Crop. Res. 2018, 227, 30-40. [CrossRef]

22. Bonin, C.; Heaton, E.A.; Cogdill, T.J.; Moore, K.J. Management of sweet sorghum for biomass production. Sugar Tech 2016, 18, 150-159. [CrossRef] 
23. Bourguignon, M.; Moore, K.J.; Brown, R.C.; Kim, K.H.; Baldwin, B.S.; Hintz, R. Variety trial and pyrolysis potential of kenaf grown in Midwest United States. BioEnergy Res. 2017, 10, 36-49. [CrossRef]

24. Winkler, B.; Mangold, A.; von Cossel, M.; Clifton-Brown, J.; Pogrzeba, M.; Lewandowski, I.; Iqbal, Y.; Kiesel, A. Implementing miscanthus into farming systems: A review of agronomic practices, capital and labour demand. Renew. Sustain. Energy Rev. 2020, 132, 110053. [CrossRef]

25. Baral, N.R.; Kavvada, O.; Mendez-Perez, D.; Mukhopadhyay, A.; Lee, T.S.; Simmons, B.A.; Scown, C.D. Techno-economic analysis and life-cycle greenhouse gas mitigation cost of five routes to bio-jet fuel blendstocks. Energy Environ. Sci. 2019, 12, 807-824. [CrossRef]

26. Casler, M.D. Heterosis and reciprocal-cross effects in tetraploid switchgrass. Crop Sci. 2014, 54, $2063-2069$. [CrossRef]

27. Casler, M.D.; Vogel, K.P. Selection for biomass yield in upland, lowland, and hybrid switchgrass. Crop Sci. 2014, 54, 626-636. [CrossRef]

28. Vogel, K.P.; Mitchell, R.B.; Casler, M.D.; Sarath, G. Registration of 'Liberty' switchgrass. J. Plant Regist. 2014, 8, $242-247$. [CrossRef]

29. Rooney, W.L.; Blumenthal, J.; Bean, B.; Mullet, J.E. Designing sorghum as a dedicated bioenergy feedstock. Biofuels Bioprod. Biorefining 2007, 1, 147-157. [CrossRef]

30. Damasceno, C.M.B.; Schaffert, R.E.; Dweikat, I. Mining genetic diversity of sorghum as a bioenergy feedstock. In Plants and BioEnergy; McCann, M., Buckeridge, M., Carpita, N., Eds.; Advances in Plant Biology; Springer: New York, NY, USA, 2014; Volume 4.

31. Maw, M.J.W.; Houx, J.H., III; Fritschi, F.B. Nitrogen use efficiency and yield response of high biomass sorghum in the lower Midwest. Agron. J. 2017, 109, 115-121. [CrossRef]

32. Mitchell, R.B.; Schmer, M.R.; Anderson, W.F.; Jin, V.; Balkcom, K.S.; Kiniry, J.; Coffin, A.; White, P. Dedicated energy crops and crop residues for bioenergy feedstocks in the Central and Eastern USA. Bioenergy Res. 2016, 9, 384-398. [CrossRef]

33. Coulman, B.; Dalai, A.; Heaton, E.; Lee, C.P.; Lefsrud, M.; Levin, D.; Lemaux, P.G.; Neale, D.; Shoemaker, S.P.; Singh, J.; et al. Developments in crops and management systems to improve lignocellulosic feedstock production. Biofuels Bioprod. Biorefining 2013, 7, 582-601. [CrossRef]

34. Khanchi, A.; Birrell, S. Drying models to estimate moisture change in switchgrass and corn stover based on weather conditions and swath density. Agric. For. Meteorol. 2017, 237-238, 1-8. [CrossRef]

35. Shinners, K.; Porter, P. Optimizing Harvest Logistics of Perennial Grasses Used for Biofuel. CenUSA Fact Sheet. Available online: https://farm-energy.extension.org/wp-content/uploads/2019/04/Factsheet1.OptimizingHarvest.pdf (accessed on 27 October 2020).

36. Lacy, N.C.; Shinners, K.J. Reshaping and recompressing round biomass bales. Trans. ASABE 2016, 59, 795-802.

37. De Souza, A.P.; Grandis, A.; Leite, D.C.C.; Buckeridge, M.S. Sugarcane as a bioenergy source: History, performance, and perspectives for second-generation bioethanol. Bioenergy Res. 2014, 7, 24-35. [CrossRef]

38. Duffield, J.A.; Johansson, R.; Meyer, S. US Ethanol: An Examination of Policy, Production, Use, Distribution, and Market Interactions; US Department of Agriculture: Washington, DC, USA, 2015.

39. EIA. EPA Finalizes Renewable Fuel Standard for 2019, Reflecting Cellulosic Biofuel Shortfalls. Available online: https://www.eia.gov/todayinenergy/detail.php?id=37712\# (accessed on 8 October 2020).

40. Dykstra, B.; Iverson, A.; Jacobs, K.; Kinzel, A.; Moore, K.; Raman, R. CenUSA Bioenergy White Paper-Emerging Markets for Switchgrass in the US Midwest: Challenges and Opportunities. 2019. Available online: https://cenusa.iastate.edu/files/cenusa_2019_075.pdf (accessed on 27 October 2020).

41. Zulauf, C. Per Acre Net Cash Return to U.S. Corn and Soybeans since 1975: Part I. Farmdoc Dly. $2015,5,181$.

42. USDA Economic Research Service. Commodity Costs and Returns. Available online: https://www.ers.usda.gov/dataproducts/commodity-costs-and-returns/commodity-costs-and-returns/\#Historical\%20Costs\%20and\%20Returns: \%20Corn (accessed on 8 October 2020).

43. H.R.6. Energy Independence and Security Act of 2007; Public Law No: 110-140; Government Printing Office: Washington, DC, USA, 2007.

44. IRENA. Advanced Biofuels: What Holds Them Back; International Renewable Energy Agency: Abu Dhabi, UAE, 2019.

45. Feather, P.; Hellerstein, D.; Hansen, L. Economic Valuation of Environmental Benefits and the Targeting of Conservation Programs: The Case of the CRP; Agricultural Economic Report No. 778, Resource Economics Division, Economic Research Service; U.S. Department of Agriculture: Washington, DC, USA, 1999. 
46. USDA Farm Service Agency. USDA Conservation Reserve Program Payments Headed to Producers. Available online: https://www.fsa.usda.gov/news-room/stakeholder-information/2019/usda-conservationreserve-program-payments-headed-to-producers\#: \{\}:text=2019\%20CRP\%20payments \%20totaled $\%$ 20more,instead\%20used\%20for\%20conservation\%20benefits (accessed on 26 October 2020).

47. Claassen, R.; Breneman, V.E.; Bucholtz, S.; Cattaneo, A.; Johansson, R.C.; Morehart, M.J. Environmental Compliance in U.S. Agricultural Policy: Past Performance and Future Potential; Agricultural Economics Reports 34033; United States Department of Agriculture, Economic Research Service: Washington, DC, USA, 2004.

48. Tilman, D.; Socolow, R.; Foley, J.A.; Hill, J.; Larson, E.; Lynd, L.; Pacala, S.; Reilly, J.; Searchinger, T.; Somerville, C. Beneficial biofuels—the food, energy, and environment trilemma. Science 2009, 325, 270-271. [CrossRef]

Publisher's Note: MDPI stays neutral with regard to jurisdictional claims in published maps and institutional affiliations.

(C) 2020 by the authors. Licensee MDPI, Basel, Switzerland. This article is an open access article distributed under the terms and conditions of the Creative Commons Attribution (CC BY) license (http://creativecommons.org/licenses/by/4.0/). 